\title{
Quality of Carica papaya seedlings grown in an alternative substrate based on buriti wood (Mauritia flexuosa Lf).
}

\author{
Qualidade de mudas de Carica papaya em substrato alternativo à base de pau de \\ buriti (Mauritia flexuosa L.f.).
}

\author{
Sammy Sidney Rocha MATIAS ${ }^{1}$; Ives Davi Louzeiro DIAS²; Yure Martins CAMELO² \\ Isnaiany Silva SOUZA²; Florizânia Ribeiro de CASTELO²; Walas Rodrigues de AGUIAR ${ }^{2}$ \\ Maysa Danielly de Souza FERREIRA²
}

${ }_{1}^{1}$ Professor Adjunto da Universidade Estadual do Piauí/UESPI, Campus Dep. Jesualdo Cavalcanti de Barros, Rua Prof. Joaquina Nogueira Oliveira, s/n, Bairro Aeroporto, 64980-000, Corrente, PI, Brasil. E-mail: ymmsa2001@yahoo.com.br ${ }^{2}$ Engenheiro-Agrônomo, Universidade Estadual do Piauí/UESPI, Corrente, Brasil. Email: ivesdavi22@gamil.com; yuremartins2@hotmail.com; Isnaianysz@gmail.com; florizaniarc@gmail.com; walasrodriguesdeaguiar@gmail.com; Maysa Danielly de Souza Ferreira

Recebido em: 18-02-2019; Aceito em: 27-05-2019

\begin{abstract}
The use of alternative organic substrates with physical, chemical and microbiological characteristics that promote the nutrition and sustenance of plants at the initial stages of development is essential to obtain satisfactory results in the production of crops. The objective of this work is to evaluate the phytotechnical characteristics of seedlings of Formosa papaya grown in a substrate based on buriti wood. The experiment was installed in a nursery located at the State University of Piauí (UESPI), campus of Corrente. The experimental design was completely randomized consisting of ten treatments and six replicates. The treatments were different percentages of buriti wood: S1 - soil; S2 - soil:buriti wood, 90/10\%; S3 - soil:buriti wood, 80/20\%; S4 - soil:buriti wood, 70/30\%; S5 - soil:buriti wood, 60/40\%; S6 - soil:buriti wood, 50/50\%; S7 - soil:buriti wood, 40/60\%; S8 - soil:buriti wood, 30/70\%; S9 soil:buriti wood, 20/80\%; S10 - soil:buriti wood, 10/90\%. The variables were height, stem diameter, root length, number of leaves, shoot dry mass, root dry mass, total dry mass, stem height/diameter ratio, shoot/root dry mass ratio, and Dickson quality index. There was significance for height, stem diameter, root length, shoot dry mass, and total dry mass. Proportions of organic residues in the substrate composition contributed to a better development of Carica papaya seedlings. Thus, the use of $40 \% \mathrm{PaB}$ mixed in the soil is recommended for the production of papaya seedlings.
\end{abstract}

Additional keywords: growth; papaya, substrate.

\section{Resumo}

O uso de substratos orgânicos alternativos com características físicas, químicas e microbiológicas, que promovam a nutrição e a sustentação das plantas nos estágios iniciais de desenvolvimento, é imprescindível para obtenção de resultados satisfatórios na produção das culturas. Objetivou-se com este trabalho avaliar as características fitotécnicas de mudas de mamoeiro tipo Formosa, produzidas com substrato à base de pau de buriti. $\mathrm{O}$ experimento foi instalado em viveiro, localizado na Universidade Estadual do Piauí (UESPI), Câmpus de Corrente. $O$ delineamento experimental utilizado foi inteiramente casualizado, constando de dez tratamentos e seis repetições. Como tratamentos, foram utilizadas diferentes porcentagens de pau de buriti: S1 - solo; S2 - solo:pau de buriti, 90/10\%; S3 - solo:pau de buriti, 80/20\%; S4 - solo:pau de buriti, 70/30\%; S5 - solo:pau de buriti, 60/40\%; S6 - solo:pau de buriti, 50/50\%; S7 - solo:pau de buriti, 40/60\%; S8 - solo:pau de buriti, 30/70\%; S9 - solo:pau de buriti, 20/80\%; e S10 - solo:pau de buriti, 10/90\%. As variáveis utilizadas foram: altura, diâmetro do caule, comprimento de raiz, número de folhas, massa seca da parte aérea, massa seca de raiz, massa seca total, relação altura/diâmetro do caule, relação massa seca da parte aérea/raiz e índice de qualidade de Dickson. Ocorreu significância para as variáveis altura, diâmetro do caule, comprimento radicular, massa seca da parte aérea e massa seca total. Proporções de resíduos orgânicos na composição de substrato contribuíram para o melhor desenvolvimento de mudas de Carica papaya. Sendo assim, recomenda-se a utilização de $40 \%$ de PaB misturado ao solo, para produção de mudas de mamoeiro.

Palavras-chave adicionais: crescimento; mamoeiro, substrato. 


\section{Introduction}

Papaya is one of the most consumed fruits in the country because of its excellent acceptance by the consumer market. This is mainly due to its organoleptic characteristics, such as sweet taste, attractive pulp color, smooth consistency, and high nutrient content (vitamins A, C and calcium). It is rich in fibers (Dantas et al., 2013).

Brazil is prominent in the world production of papaya, ranking behind only of India. The Brazilian production of papaya is very expressive, reaching about 1.057,101 tons in 2017 (IBGE, 2018). This high production is directly related to the techniques used in the crop cycle. Among them, the production of seedlings stands out since it is the main planting method of this crop and thus one of the most important stages in its productive cycle. It aims to reduce the initial cultural traits (thinning, weeding, irrigation, and sprays) and provide a greater homogeneity of plants (Salata et al., 2011).

For this, it is important to use quality seedlings, a condition that depends on the substrate. It should provide appropriate conditions for germination and a good development of roots for a fast establishment of seedlings in the field and consequently better orchards. The ideal or quality seedling should be free of pests and diseases, should have morphological characteristics (phenotypic) such as height variation between 15 and $20 \mathrm{~cm}$ after 30 days of germination, and good physiological aspects (intrinsic aspects of seedlings, nutritional status) (Dantas et al., 2013).

In addition, the cost of the material for the substrate must be taken into account as it makes production costly. Therefore, considering the high cost of commercial substrates, rural producers have been looking for solutions that provide them a better costbenefit ratio. One of the solutions is the use of materials of easy acquisition and availability in the producing region. Therefore, the use of buriti wood (Mauritia flexuosa Lf) is an option since there is a natural availability of this material in the region. The material extracted for substrate formation is acquired through the process that occurs after the plant death (Araújo et al., 2016) in a natural way (decomposition), in which the stem bark is removed and crushed, and then mixed to the material to be used. Because it is common and easily accessible in the southern region of Piauí, it is a viable alternative for the production of papaya seedlings.

Based on the above, it is necessary to seek answers based on the development of scientific studies that allow elucidating the benefits of using alternative organic substrates, such as buriti wood, in order to minimize the costs of seedlings production, thus reflecting gains and economic development. The objective of this work is to evaluate the phytotechnical characteristics of seedlings of Formosa papaya (Carica papaya L.) produced using a substrate based on buriti wood.

\section{Materials and methods}

The experiment was installed in a nursery with $50 \%$ luminosity at the State University of Piauí (UESPI)/campus of Corrente, at the geographic coordinates $10^{\circ} 26^{\prime} \mathrm{S}$ and $45^{\circ} 09^{\prime} \mathrm{W}$ and an average altitude of $438 \mathrm{~m}$ (IBGE, 2018). The climate of the region, according to the climatic classification of Köppen, is Aw', rainy tropical, with temperatures varying between $23^{\circ} \mathrm{C}$ and $39^{\circ} \mathrm{C}$, average rainfall of $900 \mathrm{~mm}$, and rainfalls concentrated from November to April.

The soil used for the composition of substrates was collected at the $0.20 \mathrm{~m}$ arable depth of a Yellow Latosol, medium texture (Santos et al., 2013). The material classified as buriti wood was collected in marsh regions from plants that were in the process of natural decomposition. The bark was extracted from the stem, and then ground. The soil and buriti wood were air-dried, dewormed, and passed through a $2 \mathrm{~mm}$ diameter sieve for material homogeneity in size. The analyses of chemical composition of the soil and the buriti wood (Table 1) were carried out at the soil chemistry laboratory of the State University of Piauí, campus of Corrente, following the methodology of Donagema et al. (2011). Then, the material was mixed to compose the substrate, according to the treatments for filling the bags, with dimensions of $0.10 \times 0.20 \mathrm{~m}$, with capacity for $0.5 \mathrm{~kg}$ of soil, remaining in rest for 30 days.

Table 1 - Chemical attributes of soil and Buriti wood (BW) used in the experiment.

\begin{tabular}{|c|c|c|c|c|c|c|c|c|c|c|c|c|c|}
\hline & $\mathrm{pH}$ & O.M & $\mathrm{N}$ & $P$ & $\mathrm{~K}^{+}$ & $\mathrm{Ca}^{2+}$ & $\mathrm{Mg}^{2+}$ & $\mathrm{Na}^{+}$ & $\mathrm{Al}^{3+}$ & $\mathrm{H}^{+}+\mathrm{Al}^{3+}$ & BS & CEC & V \\
\hline & $\mathrm{H}_{2} \mathrm{O}$ & $g \mathrm{dm}$ & $\left(\mathrm{g} \mathrm{kg}^{-1}\right)$ & 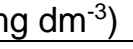 & & & & $(\mathrm{cmc}$ & $\left.\mathrm{Im}^{-3}\right)$ & & & & (\%) \\
\hline Soil & 6.5 & 15 & & 1.2 & 0.17 & 2.1 & 1.0 & 0.10 & 0.0 & 0.8 & 3.37 & 4.17 & 80 \\
\hline BW & - & - & 16.86 & 2.28 & 1.35 & 9.19 & 1.66 & - & - & - & - & - & - \\
\hline
\end{tabular}

$\mathrm{P}, \mathrm{K}^{+}$e Na+ by Melich $1\left(\mathrm{HCl}+\mathrm{H}_{2} \mathrm{SO}_{4}\right)$ extractor; $\mathrm{Al}^{3+}, \mathrm{Ca}^{2+}, \mathrm{Mg}^{2+}$ by $\mathrm{KCl} 1 \mathrm{M}$ extractor; O.M. = organic matter; $\mathrm{BS}=$ sum of bases; $\mathrm{V}=$ saturation by bases; $\mathrm{CEC}=$ cation exchange capacity.

The experimental design was completely randomized (CR) consisting of ten treatments and six replicates. The treatments were different percentages of buriti wood: S1 - soil; S2 - soil:buriti wood, 90/10\%; S3 - soil:buriti wood, 80/20\%; S4 - soil:buriti wood, 70/30\%; S5 - soil:buriti wood, 60/40\%; S6 - soil:buriti wood, 50/50\%; S7 - soil:buriti wood, 40/60\%; S8 soil:buriti wood, 30/70\%; S9 - soil:buriti wood, $20 / 80 \%$; S10 - soil:buriti wood, $10 / 90 \%$. The seedlings were produced and allocated on support benches at $0.90 \mathrm{~m}$ height.

Sowing was performed at 30 days. After prep- 
aration of the substrate, three seeds of papaya type were sown in each bag and placed at a depth of 0.02 $\mathrm{m}$. After emergence, and having the first leaves fully developed, the thinning was performed, leaving intact the most vigorous leaf. Irrigation was performed daily, manually, using a very fine sieve irrigator, allowing maintaining the humidity.

At 70 days after sowing (DAS), the following vegetative growth characteristics of papaya seedlings were evaluated: i) height $(\mathrm{H}, \mathrm{cm})$, using a ruler graduated in $\mathrm{cm}$, measured from stem base to meristematic apex; ii) stem diameter (SD, mm), measured $0.5 \mathrm{~cm}$ from the stem base using a precision digital caliper $(0.001 \mathrm{~mm})$; iii) plant height and stem diameter ratio (H/SD), obtained by dividing height by stem diameter $(\mathrm{cm} / \mathrm{mm})$; iv) root length $(R L, c m)$, determined using a millimeter rule positioned at the base of the stem up to the apex of the root; $v$ ) shoot dry mass (SDM, g): the material was dried in a forced air circulation oven at $60{ }^{\circ} \mathrm{C}$ until reaching constant weight, and then weighed on an analytical balance; vi) root dry mass (RDM, g) using the same procedure as adopted for shoot; and (vii) total dry mass (TDM, g), corresponding to the sum of SDM and RDM; viii): Dickson quality index (DQI), according to Dickson et al. (1960).

$D Q I=\frac{T D M}{(H / S D)+(S D M / R D M)}$

The correlations between the variables analyzed by Pearson's correlation $(p<0.05)$ were determined, adopting the classification proposed by Figueiredo Filho \& Silva Júnior (2009) as weak $(0.1>$ and $\leq 0.3)$, moderate $(0.4>$ and $\leq 0.6)$ and strong $(0.7>$ and $\leq 1.0)$ and using the statistical software Minitab 14 (MINITAB, 2000). Thus, a good linear correlation between two variables should have a correlation coefficient with values at least above +0.60 (positive correlation), or below -0.60 (negative correlation).

$\mathrm{H}, \mathrm{SD}$ and $\mathrm{RL}$ data were transformed by sine arc $x / 100$. For SDM and TDM, the transformation $x+C$ was used to meet the basic statistics assumptions. The analyses were performed using the software ASSISTAT, version 7.7, beta pt (Silva \& Azevedo,
2016), and the graphs were plotted using the software Sigmaplot 12.0 (SPSS, 2011). The $F$ test at $p<0.05$ of significance was applied for diagnosis of significant effects. The means of the variables regarding the factors evaluated and the interaction between them, when significant, fitted regression models. The criterion for choosing regression equations was the highest adjusted coefficient of determination.

\section{Results and discussion}

Table 2 shows the Pearson's correlation between the phytotechnical variables of papaya seedlings. By observing the relationship between variables, it is noticed that there was a significant effect at 1 and $5 \%$ probability. The analysis of the variable plant height $(\mathrm{H})$ showed a positive and significant correlation with $\mathrm{SD}, \mathrm{RL}, \mathrm{SDM}, \mathrm{RDM}, \mathrm{TDM}, \mathrm{H} / \mathrm{SD}$ and $\mathrm{DQ}$ at $\mathrm{p}<0.01$, with the exception of SDM/RDM $(p<0.05)$. This correlation is classified, according to Figueiredo Filho \& Silva Júnior (2009), as strong ( $0.7>$ and $\leq 1.0)$, that is, when one variable changes, the other also changes. The similarity or correlation between variables may have different levels. However, when this type of result is obtained (strong), it indicates that there was an effect on the relation between the substrate and the analyzed variables and that, when one variable changes, the other variable is immediately affected.

By analyzing the correlation of the SD variable (Table 2) with the others, there was a strong, positive and significant $(p<0.01)$ correlation between the variables, with the exception of SDM/RDM. Root length $(\mathrm{RL})$ correlated positively and significantly with SDM, RDM, TDM, H/SD, and DQI $\left(0.83^{\star}\right)$. This result indicates that $R L$ can affect these variables through the absorption of nutrients, water and support of seedlings in field. In general, Borges et al. (2013) and Kratz and Wendling (2013) found correlations varying between moderate and strong, positive and significant, between morphological variables and/or growth of commercial crops.

Table 2 - Pearson correlation matrix between the characteristics plant height $(H)$, stem diameter (SD), root length $(R L)$, shoot dry mass (SDM), root dry mass (RDM), total dry mass (TDM), height/stem diameter ratio (H/SD), SDM/RDM ratio, and Dickson quality Index (DQI) of the Formosa papaya seedlings.

\begin{tabular}{|c|c|c|c|c|c|c|c|c|}
\hline & $\mathrm{H}$ & SD & $\mathrm{RL}$ & SDM & RDM & TDM & $\mathrm{H} / \mathrm{SD}$ & SDM/RDM \\
\hline SD & $0.97^{\star}$ & & & & & & & \\
\hline $\mathrm{RL}$ & $0.78^{*}$ & $0.78^{*}$ & & & & & & \\
\hline SDM & $0.95^{*}$ & $0.91^{*}$ & $0.68^{\star *}$ & & & & & \\
\hline RDM & $0.90^{*}$ & $0.87^{\star}$ & $0.82^{*}$ & $0.90^{*}$ & & & & \\
\hline TDM & $0.96^{*}$ & $0.92^{*}$ & $0.74^{*}$ & $0.99^{*}$ & $0.94^{*}$ & & & \\
\hline $\mathrm{H} / \mathrm{SD}$ & $0.77^{\star}$ & $0.74^{\star}$ & $0.67^{\star *}$ & $0.59^{n s}$ & $0.69^{* \star}$ & $0.63^{* *}$ & & \\
\hline SDM/RDM & $0.66^{\star *}$ & $0.58^{\text {ns }}$ & $0.18^{\text {ns }}$ & $0.72^{*}$ & $0.52^{\text {ns }}$ & $0.68^{\text {ns }}$ & $0.38^{\text {ns }}$ & \\
\hline DQI & $0.91^{*}$ & $0.89^{*}$ & $0.83^{*}$ & $0.91^{*}$ & $0.99^{*}$ & $0.95^{\star}$ & $0.68^{* *}$ & $0.50^{*}$ \\
\hline
\end{tabular}


The SDM correlated with RDM, TDM, SDM/RDM, and DQI (Table 2). On the other hand, RDM correlated positively and significantly with TDM, $H / S D$, and DQI. The TDM was related to $H / S D$ and DQI. Albano et al. (2014) stated that the substrate must provide a good aggregation of roots in the substrate, forming a firm clump that does not disintegrate when the package is removed for planting or transportation, causing root exposition to dryness and/or mechanical damages, which hinders adhesion and survival at final planting.

The H/SD ratio correlated positively with $D Q I$ $\left(0.68^{\star *}\right)$. It was classified as moderate $(0.4>$ and $\leq 0.6$ ). The SDM/RDM had a positive effect on DQI $\left(0.50^{*}\right)$ at a $p<0.01$ level. Binotto et al. (2010), Araújo et al. (2016) and Costa Junior et al. (2017) reported that the positive correlation between DQI, H/SD, SDM/RDM and TDM shows the dependence between DQI and morphological variables, confirming the relation that exists for obtaining the Dickson quality index and these variables.

There was a significant difference for $H, R L$, $\mathrm{SD}$, SDM and TDM, evidencing that the use of $\mathrm{PaB}$ is a good option because, according to the data, there was a difference in the phytotechnical characteristics of seedlings. These values were higher than the values that compose the substrate for PaB. However, from a certain percentage of $\mathrm{PaB}$, there was a decrease in seedling growth. This may be related to the porosity and the drainage capacity of the material. The more porous the substrate is, the less its capacity to retain water, which makes it impossible to grow seedlings. According to Terra et al. (2011), the ideal substrate must have a good aeration and water retention capacity. Silva Junior et al. (2014), evaluating production of tomato seedlings in different substrates, observed that the materials that had a low aeration obtained inferior results when compared to the others. Among them, buriti wood was superior to the substrates composed of sand+soil+bovine manure and semi-decomposed carnauba residue.

Regarding $\mathrm{H}$ (Figure $1 \mathrm{~A}$ ), the highest height $(31.83 \mathrm{~cm})$ was verified when using the proportion of $\mathrm{PaB}$ of $43 \%$, with an increase of $32.73 \%$ in relation to the control. These results are superior to those obtained by Costa Junior et al. (2017), who verified that the use of $\mathrm{PaB}$ in the substrate composition for the production of papaya seedlings allowed an increase in the size of the seedlings up to the proportion of $33.5 \%$, with a maximum seedling size of $19.3 \mathrm{~cm}$. Sousa et al. (2013) found that pakara earpod tree (Enterolobium contortisiliquum) had better results when the proportion of $\mathrm{PaB}$ in the substrate was $60 \%$. Because each species has unique characteristics as to the proper conditions of the substrate for its growth, the values for the most suitable ratio may vary.

Regarding SD, the plants responded positively to the addition of $\mathrm{PaB}$ up to $44 \%$, reaching a maximum diameter of $1.44 \mathrm{~mm}$ (Figure 1B), 20.4\% higher than the control. The results of this work corroborate those obtained by Albano et al. (2014): the highest heights of papaya seedlings grown on a PaB-based substrate were obtained using the proportion $5 \%$. According to the authors, proportions above this caused deleterious effects on seedlings, reducing plant growth. According to Albano et al. (2014), the reduction in plant height is related to the direct effects of two characteristics of the substrates: $\mathrm{pH}$ and electrical conductivity (EC). One of the effects of $\mathrm{pH}$ is related to the soil/substrate nutrient solubility. In relation to EC, Cavalcante et al. (2010), studying the sources and levels of water salinity in the formation of papaya seedlings, explained that the increase in EC results in the inhibition of growth in height, stem diameter and leaf area due to the decrease in water absorption, photosynthetic rate and ion toxicity, more specifically $\mathrm{Na}^{+}$, and $\mathrm{Cl}$.

Regarding root length ( $R L$ ) (Figure $1 \mathrm{C}$ ), the highest value obtained was $35.1 \mathrm{~cm}$ with the $\mathrm{PaB}$ ratio of $38 \%$. Vasconcelos et al. (2018) observed the effects of $\mathrm{PaB}$ on the substrate when compared to other materials, such as açaí wood, sawdust powder, and black soil. The authors observed that the plants grown in the substrate composed of $\mathrm{PaB}$ obtained better results, reaching $8.36 \mathrm{~cm}$ of root length. This may be related to the benefit of the use of organic material. This is because, according to Costa et al. (2013), the decomposition of the organic material results in a high level of nutrient source for the soil since the decomposition stimulates the mineralization of the nutrients of the plant tissues.

The dry mass is considered one of the best parameters to indicate the quality of seedlings. It is compartmentalized into SDM, RDM and TDM. Although they are variables determined by destructive methods, they are indicators of survival and initial growth of seedlings in the field. The higher their mean values, the more rusted the seedlings produced will be (Araújo et al., 2016).

The shoot dry mass and total dry mass (Figures 2A and 2B) fitted the quadratic polynomial model. Regarding SDM, the proportion that resulted in the greatest shoot dry mass accumulation was $44.86 \%$, with $1.43 \mathrm{~g}$ of mass. The highest total dry mass of papaya seedlings was obtained using the proportion $46.66 \%$ and $1.54 \mathrm{~g}$ of mass. These results may be related to the good aeration of the substrate, since, according to Francisco et al. (2010), the oxygen required for root respiration is removed from the porous spaces in the substrate. Therefore, if aeration is deficient due to excessive compaction or excess of water, the root development is compromised, causing deficiency in the growth and development of the plant.

Araújo et al. (2011), evaluating the growth of seedlings Enterolobium contortsiliquum in a substrate composed of $\mathrm{PaB}$ and swine wastewater, found values different from those of this work for total dry mass. The highest values of TDM $(22.64 \mathrm{~g})$ were obtained at the $\mathrm{PaB} /$ Soil ratio of $80: 20$. 

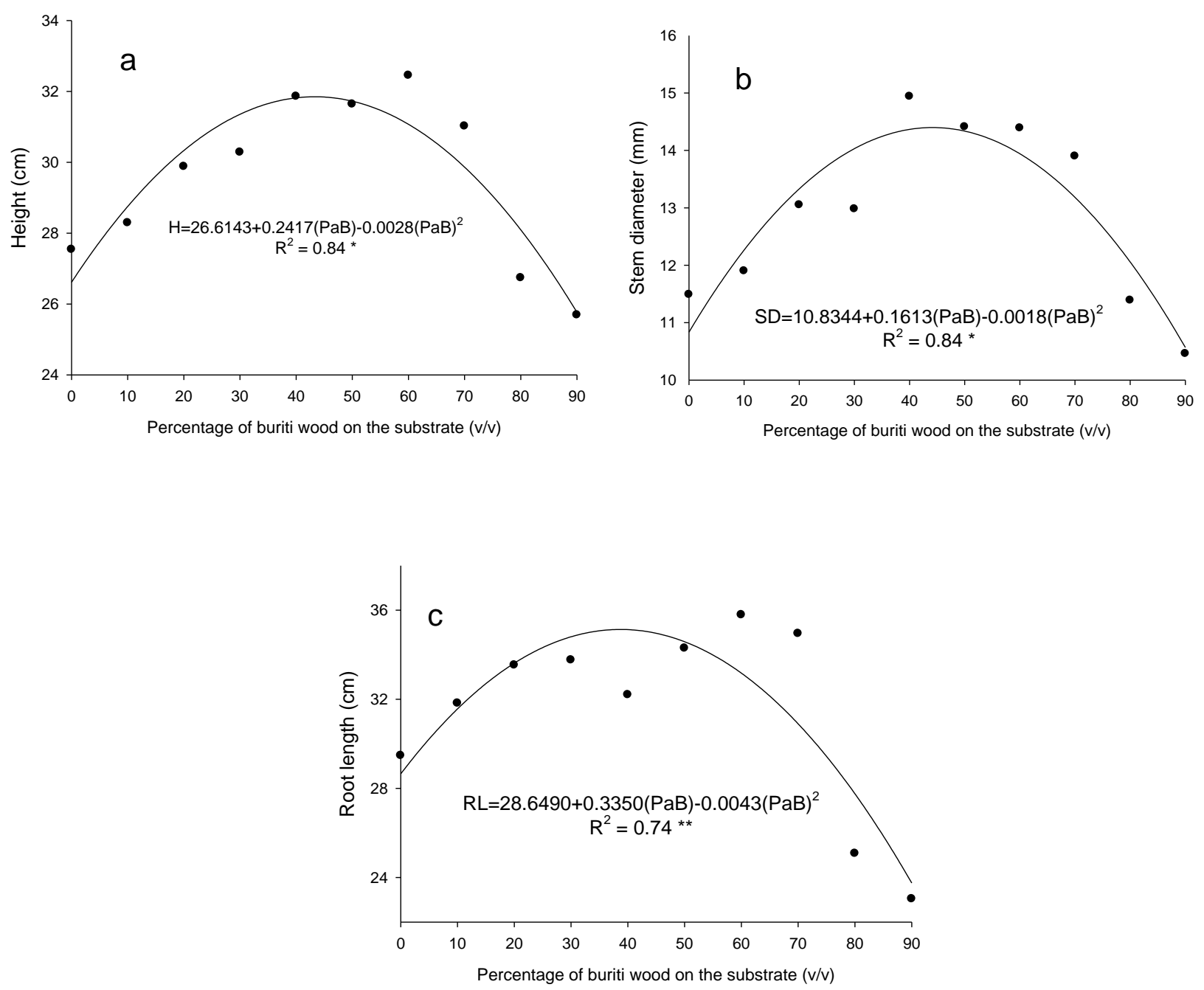

Figure 1 - Plant height (a), stem diameter (b) root length (c) of Formosa papaya seedlings as function of Buriti wood proportions in the substrate.
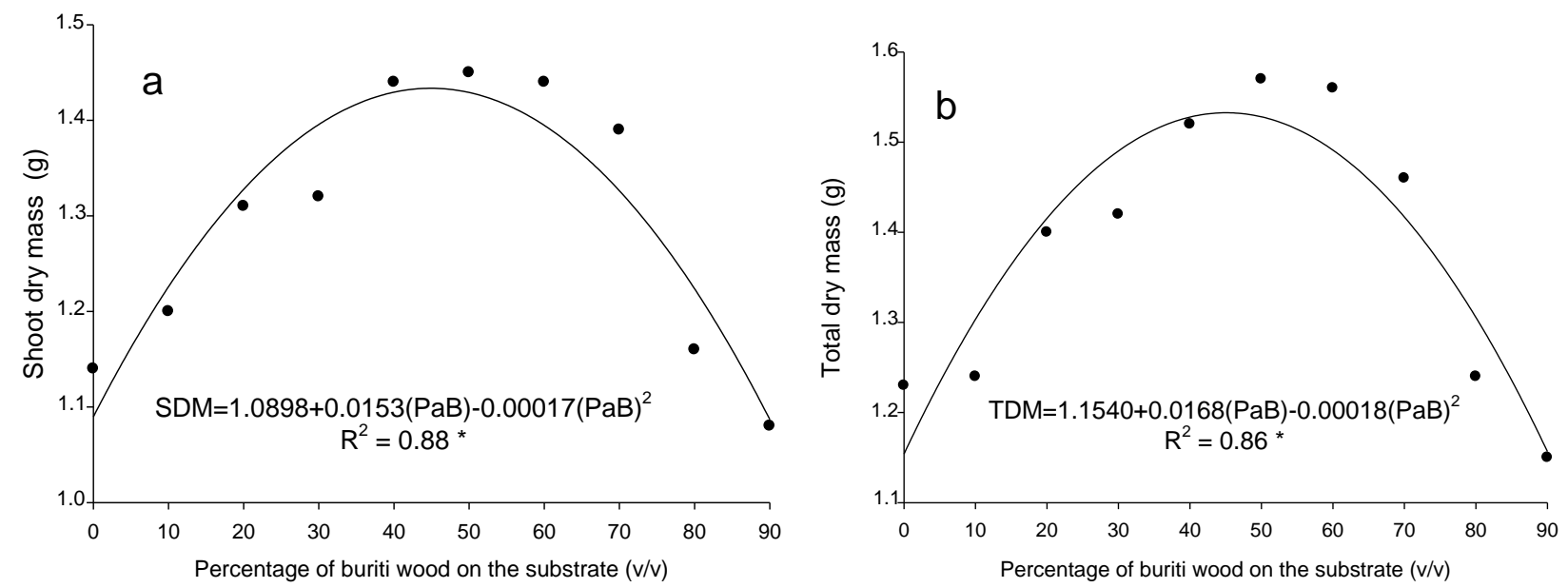

Figure 2 - Shoot dry mass (a) and total dry mass (b) of Formosa papaya seedlings as function of Buriti wood proportions in the substrate. 


\section{Conclusions}

Different proportions of organic residues in the substrate composition contribute to a better development of Carica papaya seedlings. Thus, the use of $40 \% \mathrm{PaB}$ mixed in the soil is recommended for the production of papaya seedlings.

\section{References}

Albano FG, Marques AS, Cavalcante IHL (2014) Substrato alternativo para produção de mudas de mamoeiro formosa (cv. Caliman). Científica, 42(4): 388-395. http://dx.doi.org/10.15361/19845529.2014v42n4p388-395

Araújo EF, Arauco AMS, Lacerda JJJ, Ratke RF, Medeiros JC (2016) Crescimento e balanço nutricional de mudas de Enterolobium contortsiliquum com aplicação de substratos orgânicos e água residuária. Pesquisa Florestal Brasileira, 36(86): 169. http://dx.doi.org/10.4336/2016.pfb.36.86.1135

Araújo AP, Paiva Sobrinho S (2011) Germinação e produção de mudas de tamboril (Enterolobium contortiliquum (Vell.) Morong) em diferentes substratos. Revista Árvore, 35(3): 581-588. http://dx.doi.org/10.1590/S0100-67622011000400001

Binotto AF, Dal' Col LA, Lopes SJ (2010) Correlations between growth variables and the Dickson Quality Index in forest seedlings. Cerne, 16(4), p. 457-464. http://dx.doi.org/10.1590/S0104-77602010000400005

Borges RT, Souza ERB, Naves RV, Belo APM, Camilo YMV (2013) Produções de mudas, coleções e estabelecimento de caju arbóreo do Cerrado (Anacardium othonianum Rizz.) no Estado de Goiás. Enciclopedia Biosfera, 2107p.

Cavalcante LF, Cordeiro JC, Nascimento JAM, Cavalcante IHL, Dias TJ (2010) Fontes e níveis da salinidade da água na formação de mudas de mamoeiro cv. sunrise solo. Semina: Ciências Agrárias, 31(1):1281-1290.

Costa EM, Silva HF, Ribeiro PRA (2013) Matéria Orgânica do solo e o seu papel na manutenção e produtividade dos sistemas agrícolas. Enciclopédia Biosfera, 9(17):1842-1860.

Costa Junior ES, Matias SSR, Morais DB, Sousa SJC, Santos GB, Nascimento AH (2017) Produção de mudas de Carica papaya, tipo formosa, com resíduos de pau de buriti (Mauritia flexuosa L.f.). Revista de Ciências Agrárias, 40(4): 746-755.

Dantas JL, Junghans DT, Lima JF (2013) Mamão: o produtor pergunta, a Embrapa responde. 2. ed. Brasília: Embrapa, 170p.
Dickson A, Leaf AL, Hosner JF (1960). Quality appraisal of white spruce and white pine seedling stock in nurseries. Forestry Chronicle, 36: 10-13.

Donagema GK, Campos DVBde, Calderano SB, Teixeira WG, Viana JHM (2011) Manual de métodos de análise de solos. 2. ed. Rio de Janeiro, RJ: Embrapa Solos, $230 \mathrm{p}$.

Francisco MGS, Maruyama WI, Mendonça V, Silva EA, Reis LL, Leal ST (2010) Substratos e recipientes na produção de mudas de mamoeiro 'Sunrise Solo'. Revista Agrarian, Dourados, 3(9): 267-274.

IBGE - INSTITUTO BRASILEIRO DE GEOGRAFIA E ESTATÍSTICA (2018). Produção agrícola municipal. Disponível <https://sidra.ibge.gov.br/tabela/5457\#resultado>. Acesso em: 17 setembro de 2018.

Kratz D, Wendling I (2013) Produção de mudas de Eucalyptus dunnii em substratos renováveis. Floresta, 43(1): 125-136. http://dx.doi.org/10.5380/rf.v43i1.25989.

Figueiredo Filho DB, Silva Júnior JA (2009) Desvendando os Mistérios do Coeficiente de Correlação de Pearson (r). Revista Política Hoje, 18(1): 115-146.

Minitab (2000). Release Making Data analysis Easier: version 14.

Salata AC, Higuti ARO, Godoy AR, Magro FO, Cardoso All (2011) Produção de abobrinha em função da idade das mudas. Ciência e Agrotecnologia, Lavras, 35(3): 511-515.

Santos HG dos, Jacomine PKT, Anjos LHC dos, Oliveira VA, Lumbreras JF, Coelho MR, Almeida JA de, Cunha TJF, Oliveira JB de (2013) Sistema brasileiro de classificação de solos. Brasília: Embrapa, 353p.

Silva FAS, Azevedo CAV (2016) The Assistat and its use in the analysis of experimental data (Version 7.7) [Software]. African Journal of Agricultural Research, 11 (39), 3733-3740. Recuperado de 10.5897/AJAR2016.11522

Silva Júnior JV, Beckmann-Cavalcante MZ, Brito LPS, Avelino RC, Cavalcante IHL (2014) Aproveitamento de materiais alternativos na produção de mudas de tomateiro sob adubação foliar. Revista Ciência Agronômica, 45(3):528-536.

SPSS - Systat Software Inc. (2011). SigmaPlot: For Windows (CD ROM) (Versão 12.0) [Programa de computador]. San Jose, USA: Systat Software.

Sousa WC, Nóbrega RSA, Nóbrega JCA, Brito RS, Moreira FMS (2013) Fontes de nitrogênio e caule decomposto de Mauritia flexuosa na nodulação e crescimento de Enterolobium contortsiliquum. Revista Árvore, 37(5): 969-979. 
Terra SB, Ferreira AAF, Peil RMN, Stumpf ERT, Beckmann-Cavalcante MZ, Cavalcante IHL (2011) Alternative substrates for growth and production of potted chrysanthemum (cv. Funny). Acta Scientiarum Agronomy, 33(3): 465-471.
Vasconcelos TC, Santos Júnior CF, Nunes A (2018) Substratos amazônicos para germinação e produção de mudas de alface. Enciclopédia Biosfera, 15(28): 887-895. http://dx.doi.org/10.18677/EnciBio_2018B72 http://dx.doi.org/10.4025/actasciagron.v33i3.6991 